Nepal Agric. Res. J. Vol. 9, 2009

113

RESEARCH NOTE

\title{
Use of Ethephone and Indigenous Plant Materials in Ripening Banana in Winter
}

\author{
Ram B. K.C. ${ }^{1}$, Durga.M. Gautam ${ }^{2}$ and Sundar Tiwari ${ }^{2}$ \\ ${ }^{1}$ Agricultural Research Station (Horticulture), NARC, Malepatan, Pokhara, Nepal \\ ${ }^{2}$ Institute of Agriculture and Animal Sciences, Tribhuvan University, Rampur, Chitawan, \\ Nepal
}

\begin{abstract}
Post-harvest handling of banana is a crucial activity to get good quality fruit to the consumers. A post-harvest study on ripening of banana was carried out at Regional Agriculture Research Station, Khajura during winter season of 2005 to find out the effect of different materials in ripening of banana and study about shelf-life period. Dipping fruits in Kripone $2.56 \mathrm{ml}$ per liter of water (ethephone $1000 \mathrm{ppm}$ ) for five minutes was found effective for banana ripening. Those fruits treated with ethephone $1000 \mathrm{ppm}$ started to soften in three days and became ready to consume in five days with shelf-life of eight days. Fruits treated with 'Asuro' (Adhatoda vesica) started to become soft in five days where as fruits treated with 'Koiralo' (Bahunia veriagata) became soft in four days. By using these indigenous plant materials, we can prolong shelf-life of fruit by 2-3 days more than the Kripone-treated fruits. Use of ripe banana fruit also found effective to hasten ripening the banana with excellent taste. However, the shelf-life was relatively short (8 days). It is difficult to ripen the banana in winter without using any ripening materials. In untreated control, only 33\% fruits started to become soft after 7-9 days of storage and were ready to consume in nine days. Rest $66 \%$ fruits were remain as such up to 11 days then after fruit started uneven softening ie some portion became soft and other portion remained hard. After 14 days fruits became black without softening and got spoiled. Overall percent weight loss was found 6.0 to 10.7 from initial to end of shelf-life period.
\end{abstract}

Key words: Banana, ethephone, plant materials, ripening, shelf-life

\section{INTRODUCTION}

In social and economical aspect banana (Musa acuminata) is one of the major fruits of Nepal. It occupied an area of 5732 hectare with the total productive area is 3742 hectares, which produces approximately 53257 metric of fruits (MOAC 2007). Among the major fruit crop growing area in Nepal banana stands $4^{\text {th }}$ position after citrus, mango and apple. In Nepalese geophysical situation, it 
can be grown from terai to $1500 \mathrm{~m}$ altitude of mid hills, where frost does not occur usually (Gautam and Dhakal 1991). The major production areas are terai, valleys and river basins (Bhusal et al 2008).

For nutritional security banana plays significant role in human diet by supplying vitamins, minerals and dietary fiber. Banana is the rich source of energy. Hundred grams of banana pulp provides 100 kilo calories (Khader 1990).

Both qualitative and quantitative losses occur in horticultural commodities between harvests and consumption. Qualitative losses such as loss in edibility, nutritional quality, caloric value and consumer acceptability of produce are much more difficult to assess than are quantitative losses (Kader and Rolle 2004). Banana is not usually allowed to ripen on the plant as it takes long time. Moreover, the fruit peel splits, fruit ripens unevenly and fails to develop good color and aroma, hence, the marketable quality deteriorates (Khader 1990). Therefore, banana needs to be ripened artificially. Improper maturity at harvest, miss handling during transport and lack of proper ripening technique are other causes of post-harvest losses and marketable quality. Study conducted on the post-harvest losses in different market channels in India indicated total loss of 4.86 to 18.76 per cent in different varieties (Sudhakar Rao 2007). In climacteric fruit like banana uniform ripening especially in winter season is often problematic. Poor quality and uneven ripening are caused by early harvesting and late harvesting results in extremely poor shelf-life. To extend post-harvest shelf-life of the fruit its respiration rate should be reduced at minimum tolerant level as far as possible. The most striking chemical changes which occur during the post-harvest ripening of banana are the hydrolysis of starch and the accumulation of sugar (Roy 1990).

Farmers and traders of Nepal are using different chemicals and plant materials in different doses knowingly and unknowingly. With the objectives of verifying the non hazardous chemicals and their doses and possible indigenous plants materials, this study was carried out at Regional Agriculture Research Station, Khajura, Banke.

\section{MATERIALS AND METHODS}

An experiment was conducted as a part of the 'Improvement of Quality Fruit Production and Post Harvest Handling of Banana' project supported by National Agriculture Research and Development Fund (NARDF), Government of Nepal. The experiment was carried out at Regional Agriculture Research Station of Nepal Agricultural Research Council (NARC), Khajura, Banke during winter season of 2005. Cultivar used in the study was 'Jhapali Malbhog'. Room temperature recorded during study period was maximum $27-29^{\circ} \mathrm{C}$ and minimum $20-22^{\circ} \mathrm{C}$.

The treatments include ethephone 1000, 2000, 3000 and $4000 \mathrm{ppm}$, 'Asuro' (Adhatoda vesica) 100 $\mathrm{g} / \mathrm{kg}$ fruit, 'Koiralo' (Bahunia veriagata) $100 \mathrm{~g} / \mathrm{kg}$ fruit, ripe banana four piece $/ \mathrm{kg}$ fruit, and untreated control.

\section{Procedure}

1. To obtain 1000, 2000, 3000, and 4000 ppm ediphone 2.56, 5.12, 7.68 and $10.24 \mathrm{ml}$ Kripone (ethephone 39\%) per liter of water, respectively was used. Fruits were dipped in the solution for five minutes, dried in shade, kept on Jute sacs and then covered with poly bags.

2. The fresh leaves and twigs of Asuro and Koiralo $100 \mathrm{~g}$ each per $\mathrm{kg}$ of fruits were dried in sunlight for light withering and kept as mention above. 
3. Four ripe bananas were used per $\mathrm{kg}$ of fruits to be ripened.

\section{RESULTS AND DISCUSSION}

Fruits dipped in Ethephone $1000 \mathrm{ppm}$ \{Kriphone 39\%, $2.56 \mathrm{ml}$ per liter of water\} for five minutes was effective for banana ripening so there is no need of use higher dose. Fruits started to be soften in three days and became ready to consume in five days. However, shelf-life was relatively short 8 days). After eight days fingers were detached from palm and yellow fruits turned black and got spoiled (Table 1).

'Asuro' and 'Koiralo' were found effective to ripe the banana fruit. Asuro-treated fruits started to soften in five days whereas Koiralo-treated fruits became soft in four days. By using these indigenous plant materials, we can also prolong shelf-life of fruit by 2-3 days more (Table 1). After 9-10 days fruits were spoiled by detachment of finger from palm but fruit color remained yellow. Availability of plant materials may be difficult everywhere.

Use of four fingers of ripe banana per $\mathrm{kg}$ of fruit found effective and quick to ripen the banana fruit with excellent taste. However, shelf-life was relatively short (8 days). After eight days fruits were spoiled by detaching the finger from palm and yellow fruits turn in brown color. Practical application of this method to hasten the banana ripening might be costly.

Table 1. Effect of different materials to ripening banana in winter at Khajura, 2005

\begin{tabular}{|c|c|c|c|c|c|c|c|}
\hline Treatment & $\begin{array}{l}\text { Soften } \\
\text { started } \\
\text { (days) }\end{array}$ & $\begin{array}{c}\text { Suitable } \\
\text { for use } \\
\text { (days) }\end{array}$ & $\begin{array}{l}\text { Color } \\
\text { scale }\end{array}$ & $\begin{array}{c}\text { Attend } \\
\text { completely } \\
\text { yellow } \\
\text { (days) }\end{array}$ & $\begin{array}{l}\text { Shelf- } \\
\text { life } \\
\text { (days) }\end{array}$ & $\begin{array}{c}\text { Brix, } \\
\%\end{array}$ & Taste \\
\hline $\begin{array}{l}\text { Ethephone } 1000 \\
\text { ppm }\end{array}$ & 3.00 & 4.00 & 3 & - & 8 & 11.00 & Excellent \\
\hline $\begin{array}{l}\text { Ethephone } 2000 \\
\text { ppm }\end{array}$ & 3.00 & 5.30 & 3 & 8 & 8 & 13.00 & Excellent \\
\hline $\begin{array}{l}\text { Ethephone } 3000 \\
\text { ppm }\end{array}$ & 3.00 & 4.00 & 3 & - & 8 & 11.20 & Excellent \\
\hline $\begin{array}{l}\text { Ethephone } 4000 \\
\text { ppm }\end{array}$ & 3.00 & 4.67 & 3 & 7 & 7 & 13.06 & Excellent \\
\hline Adhatoda vesica & 4.67 & 6.00 & 3 & 8 & 10 & 11.33 & Good \\
\hline Koiralo & 4.00 & 6.00 & 5 & 7 & 9 & 10.33 & Good \\
\hline Ripe banana & 3.00 & 4.33 & 3 & 7 & 8 & 9.53 & Excellent \\
\hline Untreated control & 9.00 & 9.33 & - & - & - & 9.53 & - \\
\hline Grand mean & 4.083 & 5.45 & - & - & 3.706 & 11.125 & \\
\hline $\operatorname{LSD}(\mathrm{a}=0.05)$ & 1.159 & 0.946 & - & - & 1.576 & ns & \\
\hline F-test & $* *$ & $* *$ & - & - & $* *$ & & \\
\hline $\mathrm{CV}, \%$ & 16.14 & 9.89 & - & - & 10.33 & & \\
\hline
\end{tabular}

Color scale: 3, More green than yellow. 5, More yellow than green.

In winter season, it is very difficult to ripen the banana commercially without using any materials. In untreated control, only 33 percent fruits started to become soft after 7-9 days and ready to consume in nine days. Rest 66 percent fruits remained as such up to 11 days. Then after fruits started uneven 
softening i.e. some portions became soft and some portions remained hard. Fruits also failed to develop color and aroma. After 14 days fruits became black without softening and yellowing. The loss of weight was the highest in the 'Koiralo' treatment and the least in untreated control.

Table 2. Weight loss trend of ripe banana over shelf life period

\begin{tabular}{lcccccc}
\hline Treatment & & $\begin{array}{c}\text { Initial } \\
\text { weight, } \\
\mathrm{g}\end{array}$ & $\begin{array}{c}\text { 4 days of } \\
\text { storage }\end{array}$ & $\begin{array}{c}8 \text { days } \\
\text { of } \\
\text { storage }\end{array}$ & $\begin{array}{c}\text { Total wt loss at } \\
\text { the end of } \\
\text { shelf-life, }\end{array}$ & $\begin{array}{c}\text { Weight loss, } \\
\%\end{array}$ \\
\hline $\begin{array}{l}\text { Ethephone } \\
\text { ppm }\end{array}$ & 1000 & 920 & 903 & 845 & 75 & 8.1 \\
$\begin{array}{l}\text { Ethephone } \\
\text { ppm }\end{array}$ & 2000 & 951 & 932 & 873 & 78 & 8.2 \\
$\begin{array}{l}\text { Ethephone } \\
\text { ppm }\end{array}$ & 3000 & 902 & 888 & 831 & 71 & 7.8 \\
$\begin{array}{l}\text { Ethephone } \\
\text { ppm }\end{array}$ & 4000 & 926 & 908 & 870 & 56 & 6.0 \\
$\begin{array}{l}\text { Asuro } \\
\text { Bahunia veriagata }\end{array}$ & 842 & 840 & 799 & 79 & 9.3 \\
$\begin{array}{l}\text { Ripe banana } \\
\text { Untreated control }\end{array}$ & 901 & 899 & 888 & 829 & 72 & 7.9 \\
\hline
\end{tabular}

\section{CONCLUSION}

Uses of ethephone, indigenous plant materials (Asuro and Koiralo), ripe banana fingers were found effective to ripen banana. Further modification/verification for their use in large scale and studies on other indigenous materials should be explored.

\section{ACKNOWLEDGEMENTS}

National Agriculture Research and Development Fund (NARDF) is acknowledged for supporting this research work. Our thanks also go to Mr YR Bhusal, ARS-Malepatan, Pokhara for data processing and going through the manuscript. Help provided by Mr KB Chanda, RARS-Khajura is highly appreciated.

\section{REFERENCES}

Bhusal,Y.R., M.S. Ghale and H.P. Pathak 2008. Evaluation of different Varieties of Banana at Agriculture Research Station (Horticulture), Malepatan, Pokhara. Paper presented at $5^{\text {th }}$ National Horticulture Seminar June 9-10, Khumaltar, Lalitpur.

Gautam DM and DD Dhakal. 1991. Falful Tatha Audhogik Bali (In Nepali). Pavitra and Rupa publication, Bharatpur, Chitwan.

Kader AA and RS Rolle. 2004. The role of post-harvest management in assuring the quality and safety of horticultural produce. FAO Agricultural Services Bulletin 152. 
Khader A, JBM Md, K Chellappan, PK Chattopadhayay and O Anchanam Alagia Pillai. 1990. Banana. In: Fruits Tropical and Subtropical (TK Bose and SK Mitra, eds.). Naya Prokash, Calcutta. Pp. 132-185.

MOAC. 2007. Statistical information on Nepalese agriculture (2006/07). Agribusiness Promotion and Statistics Division, Ministry of Agriculture and Cooperatives, Government of Nepal, Singha Durbar, Kathmandu, Nepal.

Roy SK. 1990. Post-harvest handling of fresh fruit. In: Fruits tropical and subtropical (TK Bose and SK Mitra, eds.). Naya Prokash, Calcutta.

Sudhakar Rao DV. 2007. Minimization of post-harvest losses of fruits and vegetables. Division of Post-harvest Technology, Indian Institute of Horticultural Research, Hessarghatta Lake, Bangalore. 